\title{
Return on investment from the use of product configuration systems - A case study
}

\author{
Kristjansdottir, Katrin; Shafiee, Sara; Hvam, Lars; Bonev, Martin; Myrodia, Anna
}

Published in:

Computers in Industry

Link to article, DOI:

10.1016/j.compind.2018.04.003

Publication date:

2018

Document Version

Peer reviewed version

Link back to DTU Orbit

Citation (APA):

Kristjansdottir, K., Shafiee, S., Hvam, L., Bonev, M., \& Myrodia, A. (2018). Return on investment from the use of product configuration systems - A case study. Computers in Industry, 100, 57-69.

https://doi.org/10.1016/j.compind.2018.04.003

\section{General rights}

Copyright and moral rights for the publications made accessible in the public portal are retained by the authors and/or other copyright owners and it is a condition of accessing publications that users recognise and abide by the legal requirements associated with these rights.

- Users may download and print one copy of any publication from the public portal for the purpose of private study or research.

- You may not further distribute the material or use it for any profit-making activity or commercial gain

- You may freely distribute the URL identifying the publication in the public portal

If you believe that this document breaches copyright please contact us providing details, and we will remove access to the work immediately and investigate your claim. 


\section{Return on Investment from the Use of Product Configuration Systems - A Case Study}

Product configuration systems (PCS) are increasingly being used in industrial companies to enable the efficient design of customized products. The literature describes substantial benefits that companies have achieved from the use of PCS, such as reduced resource consumption, reduced lead-time, improved quality, and increased sales, which should lead to a significant return on investment (ROI). However, there is little detailed quantification of the benefits, costs, and ROI from using PCS in the literature. Thus, the true value of PCS remains unknown. Hence, this study quantifies (1) the benefits in terms of reduced man-hours, improved quality of specifications, reduced lead-time, and increased sales and (2) the costs of development, implementation, and maintenance of PCS. Based on this, the ROI is calculated. The analyses presented in this study are based on a world-leading company in pump manufacturing. This study verifies the benefits of PCS that are described in the literature. Further, it contributes to the field by introducing a method to quantify the related benefits, costs, and ROI. Finally, the article illustrates how PCS can be used in companies having product portfolios consisting of a standard to engineered products.

Keywords: information systems, mass customization, product configuration system (PCS), cost-benefit analysis, case study 


\section{Introduction}

In today’s business environment, customers are increasingly demanding customized products that can be delivered within a quick turnaround time and at competitive prices [1]. In response to the emerging challenges, mass customization strategies have received increased attention from both industrial practitioners and researchers in recent decades. Mass customization refers to the ability to provide customized products and services with flexibility and at a cost similar to that of mass-produced products [2]. To enable the successful implementation of mass customization, companies need to develop a solution space that can enable robust process design and navigational choice over the existing systems [3]. One way of achieving mass customization is by designing more modular products for which a product configuration system (PCS) is used in the customization process [2]. A PCS is used to support design activities throughout the customization process, during which a set of components and their connections are predefined and constraints are developed to prevent infeasible configurations [4].

The literature describes numerous benefits of implementing a PCS to support specification processes. A specification process can be defined as a process that is concerned with generating different product specifications (e.g., quotes, sales prices, bill of materials, CAD models), which normally involves employees from different departments [1,5]. Companies utilizing a PCS demonstrate better capability in terms of offering a variety of products, improving product quality, simplifying the customerordering process, and reducing the complexity of both processes and products, in addition to increased product profitability [6-10]. Further, a PCS facilitates knowledge sharing, uses fewer resources, optimizes product designs, performs less routine work, ensures timely delivery, reduces the time required to train new employees, and augments the product related and experience related benefits perceived by customers [1,11-20]. 
The literature confirms that companies can achieve a positive return on investment (ROI) from using PCS [21-24]. However, while the literature explains both the benefits and the ROI from using a PCS, further research is needed to understand the process leading to this value creation and to perform a comparison of the benefits (e.g., reduced man-hours and lead-time, improved quality, or increased sales) and the cost (e.g., the development, implementation, and maintenance) of the PCS. ROI is used to measure the ratio of cost to benefit, and it is a performance measure that is employed to evaluate the efficiency of a number of different investments [25].

The aim of this article is, therefore, to provide more understanding of the value creation from implementing and utilizing a PCS and to provide an operational method to evaluate this value creation. More specifically, the objective of the article is to analyze the benefits and costs so that ROI can be calculated. Additionally, the process changes and the product coverage of the PCS are elaborated based on a case company, which is a global manufacturing firm with a product portfolio consisting of a standard to engineered products. To address these issues, the following research questions are developed:

$R Q$ 1: How to quantify the costs, benefits and ROI from developing, implementing and utilizing PCS?

$R Q$ 2: What are the costs, benefits, and ROI from developing, implementing and utilizing a PCS?

To answer the research question, this article first determines whether prior research quantifies the benefits, costs and ROI of developing, implementing and utilizing a PCS. Additionally, the literature is reviewed to identify the different production strategies in companies making both standard and engineered products and 
how a PCS support these activities. Next, a case study was conducted at Grundfos, which is a global company producing industrial pumps that utilize a PCS to support its sales and specification processes.

The remainder of this paper is organized as follows. Section 2 presents a literature review, and Section 3 describes the research method. Section 4 contains the main results of the case study analysis. Finally, Section 5 discusses these results, generates the conclusions, and provides a direction for future research.

\section{Literature review}

In this section, the literature background for the study is presented, first, in terms of the PCS and different manufacturing strategies. Second, the benefits, costs, and ROI are elaborated. Finally, based on the relevant literature, we establish our research focus.

\subsection{PCS and product structure}

The configuration task can be described in terms of a pre-defined set of components, which are described by a set of properties (attributes) and their values, connections of the components (parts), and constraints to prevent infeasible configurations [4,26]. A PCS can be implemented both to support the end-user of the product and/or as an internal tool to increase efficiency by improving the dialogue with the customer and automating the generation of product specifications $[1,5,15,17,27,28]$.

In line with the configuration task, companies need to define parts/modules and constraints that ensure that only allowed combinations can be selected. Product architecture can be defined as (1) the arrangement of functional elements; (2) the mapping from functional elements to physical components; or (3) the specification of the interfaces among interacting physical components. [29]. The highest degree of modularity occurs when each functional requirement can be directly connected to one 
module and where there are few interactions between the modules, making it possible to change specific modules without affecting other parts of the design [30].

The customer-order-decoupling point (CODP), distinguishes between the work carried out before and after the customer places the order and is commonly defined to classify companies’ order fulfilment strategies [1]. Thus, the CODP can also be defined in terms of the separation of decisions made under uncertainty from decisions are made based on customers' demand, where the position of the CODP determines the optimal balance between productivity and flexibility in companies [31]. The literature discusses configure-to-order (CTO) versus engineer-to-order (ETO) strategies, where CTO strategies are based on combinations of modules/components according to the rules defined in the PCS, whereas ETO denotes orders for which it is necessary to go beyond the modules/components and rules defined in the PCS when designing customized products [1,6,32]. Many companies however operate in a span between CTO and ETO strategies where it can be a challenging task to find the appropriate degree of standardization and automation [33-36]. Wikner and Rudberg [35] elaborate on the CODP, which focuses on the production dimension, by adding the engineering dimension. Different archetypes of ETO companies (i.e., complex ETO, basic ETO, repeatable ETO and non-competitive ETO) can be defined based on engineering complexity (man-hours used for engineering of a product) and volume (units of products sold on yearly base) [34]. Another classification of ETO companies is presented by Gosling et al. [36] based on customer penetration concepts where nine potential subclasses are proposed.

\subsection{Economic value creation from implementing and utilizing a PCS}

The PCS literature describes numbers of benefits from using these systems. In particular, three benefits are widely discussed and considered to be directly linked to cost savings: (1) a reduction in resource consumption (man-hours) and lead-time, (2) 
improved quality of product specifications, and (3) increased sales. Second, previous works that have addressed the cost in relation to a PCS, which is defined based on the cost of developing, implementing, and maintaining the systems, is reviewed. Third, the literature that has addressed the ROI related to a PCS is elaborated.

\subsubsection{Cost savings related to the benefits of implementing a PCS}

Previous works have shown that the use of a PCS results in reduced man-hours and lead-time when generating product specifications [6,17,21,23,24,37-50]. Even though this benefit is the most commonly mentioned and quantified in previous studies, the literature does not explain the extent to which reduced man-hours and lead-time result in direct cost savings. Table 1 summarizes the studies that quantify the reduction in man-hours and lead-time due to the utilization of a PCS.

Table 1 . Works that quantify a reduction in man-hours and lead-time due to the utilization of a PCS

\begin{tabular}{|c|c|c|}
\hline Research Work & Method & Contribution \\
\hline $\begin{array}{l}\text { Forza and Salvador } \\
{[24]}\end{array}$ & $\begin{array}{l}\text { Case study of one } \\
\text { company }\end{array}$ & $\begin{array}{l}\text { - The PCS reduced the amount of time required } \\
\text { for manned activities in the tendering process } \\
\text { from } 5-6 \text { days to } 1 \text { day. }\end{array}$ \\
\hline $\begin{array}{l}\text { Forza, Trentin and } \\
\text { Salvador }[40]\end{array}$ & $\begin{array}{l}\text { Case study of one } \\
\text { company }\end{array}$ & $\begin{array}{l}\text { - The average time needed to make an offer was } \\
\text { reduced from } 1-2 \text { days to a few hours, and for } \\
\text { technical specifications, from } 2.5 \text { days to a few } \\
\text { minutes. }\end{array}$ \\
\hline \multirow[t]{2}{*}{$\begin{array}{l}\text { Haug, Hvam and } \\
\text { Mortensen [41] }\end{array}$} & Survey & $\begin{array}{l}\text { - On average, the lead-time required to generate } \\
\text { proposals was reduced by } 83.7 \% \text {. }\end{array}$ \\
\hline & & $\begin{array}{l}\text { - The man-hours in the configuration process } \\
\text { were reduced by up to } 78.4 \% \text {. }\end{array}$ \\
\hline \multirow[t]{2}{*}{$\begin{array}{l}\text { Heiskala, Paloheimo } \\
\text { and Tiihonen [42] }\end{array}$} & $\begin{array}{l}\text { Case study of two } \\
\text { companies }\end{array}$ & $\begin{array}{l}\text { - The average selection time was reduced from } 2 \\
\text { hours to } 6 \text { minutes. }\end{array}$ \\
\hline & & $\begin{array}{l}\text { - The throughput cycle was reduced from } 6 \text { days } \\
\text { to } 1 \text { day. }\end{array}$ \\
\hline \multirow[t]{2}{*}{ Hvam et al. [45] } & $\begin{array}{l}\text { Case study of one } \\
\text { company }\end{array}$ & $\begin{array}{l}\text { - The lead-time required to generate tenders was } \\
\text { reduced from } 15-25 \text { days to } 1-2 \text { days. }\end{array}$ \\
\hline & & $\begin{array}{l}\text { - The amount of time required for engineering in } \\
\text { the quotation process was reduced from } 5 \text { weeks } \\
\text { to } 1-2 \text { days. }\end{array}$ \\
\hline Hvam [46] & $\begin{array}{l}\text { Case study of one } \\
\text { company }\end{array}$ & $\begin{array}{l}\text { - The real working time for preparing offers and } \\
\text { production instructions was close to } 0 .\end{array}$ \\
\hline
\end{tabular}




\begin{tabular}{|c|c|c|}
\hline & & $\begin{array}{l}\text { - The delivery time was reduced from 11-41 days } \\
\text { to } 1 \text { day. }\end{array}$ \\
\hline Hvam [47] & $\begin{array}{l}\text { Case study of one } \\
\text { company }\end{array}$ & $\begin{array}{l}\text { - The resources required to generate the } \\
\text { quotations were reduced by } 50 \% \text {. }\end{array}$ \\
\hline \multirow[t]{2}{*}{ Hvam et al. [48] } & $\begin{array}{l}\text { Case study of four } \\
\text { companies }\end{array}$ & $\begin{array}{l}\text { - The lead-time required to generate an offer was } \\
\text { reduced by } 94-99 \% \text {. }\end{array}$ \\
\hline & & $\begin{array}{l}\text {-The resources needed to create product } \\
\text { specifications were reduced by } 50-95 \% \text {. }\end{array}$ \\
\hline
\end{tabular}

Improved quality due to more accurate product specifications is another benefit of a PCS that is frequently described in the literature $[6,8,17,21-24,37-51]$. This improvement in quality can be attributed to the reduced number of errors in product specifications. Table 2 summarizes the research that quantifies improvements in quality as a result of utilizing a PCS.

Table 2. Literature that quantifies improvements in data quality due to the use of a PCS

\begin{tabular}{|c|c|c|}
\hline Research Work & Method & Contribution \\
\hline Forza and Salvador [6] & $\begin{array}{l}\text { Case study of one } \\
\text { company }\end{array}$ & - Errors in configurations declined to almost 0. \\
\hline $\begin{array}{l}\text { Forza and Salvador } \\
\text { [24] }\end{array}$ & $\begin{array}{l}\text { Case study of one } \\
\text { company }\end{array}$ & $\begin{array}{l}\text { - The correctness of product information } \\
\text { increased to almost } 100 \% \text {. }\end{array}$ \\
\hline $\begin{array}{l}\text { Heiskala, Paloheimo, } \\
\text { and Tiihonen. [42] }\end{array}$ & $\begin{array}{l}\text { Case study of two } \\
\text { companies }\end{array}$ & $\begin{array}{l}\text { - Quality of specifications improved from } 60 \% \text { to } \\
100 \% \text {, and specifications were always ready for } \\
\text { manufacture (without errors). } \\
\text { - The pricing accuracy improved from } 80 \% \text { to } \\
100 \% \text {. }\end{array}$ \\
\hline Hvam [46] & $\begin{array}{l}\text { Case study of one } \\
\text { company }\end{array}$ & $\begin{array}{l}\text { - The number of assembly errors was reduced } \\
\text { from } 30 \% \text { to less than } 2 \% \text {. }\end{array}$ \\
\hline Sviokla [23] & $\begin{array}{l}\text { Case study of one } \\
\text { company }\end{array}$ & $\begin{array}{l}\text { - The accuracy of product specifications improved } \\
\text { from } 65-90 \% \text { to } 95-98 \% \text {. }\end{array}$ \\
\hline Yu and Skovgaard [51] & $\begin{array}{l}\text { Case study of one } \\
\text { company }\end{array}$ & - The configuration accuracy reached $100 \%$. \\
\hline
\end{tabular}

Previous research also describes how increased sales can be achieved, as salespersons are able to respond to all customers due to the increased throughput enabled by a PCS $[43,44,47,48]$. Although increased sales is mentioned as a benefit of utilizing a PCS, this impact remains largely unaddressed. The literature has also not quantified the relationship between a PCS and increased sales. 


\subsection{Cost elements in relation to a PCS}

Few researchers have addressed the cost elements related to a PCS. Forza and Salvador [6] mention that a high investment in terms of man-hours might be needed to introduce PCS into a company. According to Hvam [47], the cost of developing and implementing a PCS in a case company is approximately USD 1 million, with operating costs of USD 100,000 per year. These costs are compared with the usage of the PCS that generates a budget and detailed quotations, with an estimated total sales price of USD 500 million. However, Hvam [47] does not link the benefits of utilizing a PCS to the actual cost; the cost is compared to the sum of the total sales price in the quotations generated by the PCS. Table 3 summarizes the previous research quantifying the cost elements related to a PCS.

Table 3. Literature that quantifies the cost elements related to a PCS

\begin{tabular}{lll}
\hline Research Work & Method & Contribution \\
\hline Hvam [47] & $\begin{array}{l}\text { Case study based on } \\
\text { one company }\end{array}$ & $\begin{array}{l}\text { The overall cost of developing and implementing } \\
\text { a PCS is approximately USD } 1 \text { million, and the } \\
\text { operating cost is around USD 100,000 per year. }\end{array}$ \\
\hline
\end{tabular}

\subsubsection{Return on investment from using a PCS}

Few researchers have elaborated on ROI in relation to a PCS. Barker et al. [21] do not discuss the ROI but rather the net return of the system, which is estimated to be in excess of USD 40 million. In another study, Fleischanderl et al. [22] report that the PCS in a case company achieved a positive ROI within its first year of operation. Finally, Forza and Salvador [24] describe how small enterprises can benefit from implementing PCS, where not only a rapid ROI but also a competitive advantage can be anticipated.

Table 4 summarizes the research that quantifies the savings accrued from the use of a PCS.

Table 4. Literature that quantifies the return on investment from the use of a PCS

\begin{tabular}{lll}
\hline Research Work & Method & Contribution \\
\hline
\end{tabular}




\begin{tabular}{lll}
\hline Barker et al. [21] & $\begin{array}{l}\text { Case study based on } \\
\text { one company }\end{array}$ & $\begin{array}{l}\text { - Overall net return of the PCS is over USD } 40 \\
\text { million. }\end{array}$ \\
Fleischanderl et al. [22] & $\begin{array}{l}\text { Case study based on } \\
\text { one company }\end{array}$ & $\begin{array}{l}\text { - Using the PCS to support the complete } \\
\text { configuration process was shown to reduce } \\
\text { products lifecycle costs by up to } 60 \% .\end{array}$ \\
& $\begin{array}{l}\text { - The PCS had a positive ROI within its first year } \\
\text { of operation. }\end{array}$ \\
Sviokla [23] & $\begin{array}{l}\text { Case study based on } \\
\text { one company. }\end{array}$ & $\begin{array}{l}\text { other savings from previous years, given that an } \\
\text { expensive testing phase is not required. }\end{array}$ \\
\hline
\end{tabular}

\subsubsection{Summary}

Thus, a number of works in the literature have quantified the benefits of a PCS including the reduced man-hours, lead-time, and quality of product specifications. However, the research does not link those benefits to the actual costs accrued in these companies. Only Hvam [47] mentions and quantifies the cost of PCS development and implementation. Further, in terms of ROI, only Barker et al. [21] quantify the net return while Sviokla [23] quantifies the savings; however, they do not break down the net return, into cost savings and cost elements. Thus, the quantification of costs and benefits from using PCS remains unaddressed in the literature, as does the ROI. To understand the circumstances under which companies can achieve this ROI, this article also elaborates on the process changes undertaken and the product coverage of the system in the case company with regard to CTO and ETO products.

\section{Research Method}

To examine the benefits, costs, and the ROI of PCS, this article presents a case study conducted at Grundfos. The company operates worldwide and has a mixed product portfolio varying from standard to engineered pumps. The company has used a PCS since 2001, which allows analysis of the long-term ROI from using a PCS. Further, access to the company and its data allow this analysis to be performed within an industrial setting. For the analyses presented in this article, two product families are 
selected. The analyses examine cost and benefit data. The overall cost is divided into development, implementation, and maintenance costs. The development took place over a two-year period, and the implementation is considered as a one-time pay-off when the system is launched. Further data on the benefits and maintenance costs are considered after the system became operational and are gathered over a five-year period.

The main strength of case research is that a phenomenon can be studied in its natural settings, allowing why, what, and how questions [52,53]. This motivates the use of case research to answer the presented research questions in this study of "how" and "what.” Further, a case study is defined as "a study that investigates a contemporary phenomenon (the 'case') in depth and in its real-world context, especially when the boundaries between phenomenon and context may not be clearly evident” [54]. The phenomenon investigated in this study is the ROI of a PCS, and the context is global manufacturing company producing both standard and engineered products. Further, case studies enable a deeper understanding of the relationships among the different variables and phenomena that are not fully examined or understood [53], which motivates the selection of case study approach for this research.

Single cases allow a phenomenon to be studied in more detail, but the main disadvantage is a lack of generalizability [52]. However, this limitation can be overcome through the use of using multiple cases, to evaluate whether the findings are distinctive to a single case or consistently replicated over several cases, although this may not allow as in-depth study of the phenomenon since more resources are required $[52,55]$. Thus, as this is defined as an explorative study, the focus is on obtaining an indepth understanding of the case company and the utilization of the PCS. To this end, multiple data sources are used in this research to triangulate the data and overcome the limitation of using only one data collection method [56]. Further, the literature reflects 
on the quantification of the benefits relating to reduced man-hours and lead-time that allows comparison to other previous studies to validate the results presented (see Tables 1-4). The majority of the studies focusing on the benefits from utilizing PCS are based on single case studies (see Tables 1-4). Thus, by selecting a single case study design allows for comparison of the obtained results demonstrated in the literature [57].

\subsection{Data gathering}

Multiple data sources were used, where both quantitative and qualitative data is gathered to allow for triangulation [56]. Quantitative data is retrieved from e.g., internal systems at the company and from project reports and is supported by qualitative data, which is gathered based on interviews with managers (9), specialists (5) and engineers (6) at the company. Table 5 shows the data required and the sources used to gather data in this study.

Table 5. Required data and sources of data

\begin{tabular}{|l|l|l|l|}
\hline Context area & $\begin{array}{l}\text { Unit of } \\
\text { measurement }\end{array}$ & Data to be collected & Source of information \\
\hline $\begin{array}{l}\text { Process flow } \\
\text { descriptions }\end{array}$ & - & $\begin{array}{l}\text { Process flow before and after the } \\
\text { implementation of the PCS for } \\
\text { standard and non-standard } \\
\text { products respectively. }\end{array}$ & Interviews \\
\hline $\begin{array}{l}\text { Time required to } \\
\text { generate } \\
\text { specifications and } \\
\text { the overall lead- }\end{array}$ & Man-hours & $\begin{array}{l}\text { The man-hours used for the } \\
\text { different steps of the } \\
\text { specification process before and } \\
\text { after implementing the PCS. } \\
\text { The overall lead-time (from } \\
\text { customer asks for proposal until } \\
\text { the specifications have been } \\
\text { generated) before and after } \\
\text { implementing the PCS. }\end{array}$ & Interviews \\
\hline $\begin{array}{l}\text { Quantity of sales } \\
\text { exrons in generated }\end{array}$ & $\begin{array}{l}\text { No. of } \\
\text { products sold }\end{array}$ & $\begin{array}{l}\text { Sales quantity of products } \\
\text { supported by the PCS (i.e. light } \\
\text { ETO products and CTO products). } \\
\text { Data supporting who uses the } \\
\text { PCS (i.e. if the user of the PCS is } \\
\text { from the LSO or CSU). }\end{array}$ & ERP system \\
\hline
\end{tabular}




\begin{tabular}{|l|l|l|l|}
\hline specifications & types & $\begin{array}{l}\text { made without the PCS } \\
\text { respectively. }\end{array}$ & $\begin{array}{l}\text { Study of the quality of } \\
\text { the specifications }\end{array}$ \\
\hline Increase in sales & - & $\begin{array}{l}\text { Indications if the PCS stimulated } \\
\text { increased sales at the company. }\end{array}$ & Interviews \\
\hline $\begin{array}{l}\text { Cost of the PCS } \\
\text { (development, } \\
\text { implementation, } \\
\text { and maintenance) }\end{array}$ & Man-hours & $\begin{array}{l}\text { Man-hours used for developing, } \\
\text { implementing and maintaining } \\
\text { the PCS and cost of the software. }\end{array}$ & $\begin{array}{l}\text { Interviews } \\
\text { Project reports }\end{array}$ \\
\hline
\end{tabular}

The interviewees included employees from the following departments: the local sales offices (LSO), customer support unit (CSU), production, distribution, development and engineering, product management and product data management. Employees from the different departments are interviewed to capture different perspectives within the company - some employees are interviewed more than once. Even though the interviewees belong to different departments (context area), the same questions guidelines are used. The semi-structured interviewing approach is adopted in this research to allow adjustments during the interviews and thus capture additional information or perspectives. Table 6 lists the departments from which the employees have been chosen to be interviewed and the questions asked.

Table 6. Questions guidelines and employees addressed for interviews

\begin{tabular}{|c|c|c|}
\hline Context area & $\begin{array}{l}\text { Department (No. } \\
\text { of employees } \\
\text { interviewed) }\end{array}$ & Questions \\
\hline $\begin{array}{l}\text { Process flow } \\
\text { descriptions } \\
\text { (Before and } \\
\text { after } \\
\text { implementing } \\
\text { PCS) }\end{array}$ & $\begin{array}{l}\text { LSO (2) } \\
\text { CSU (2) } \\
\text { Development and } \\
\text { engineering (1) } \\
\text { Production (1) } \\
\text { Distribution (1) }\end{array}$ & $\begin{array}{l}\text { Before and after implementation of the PCS the following } \\
\text { questions are asked } \\
\text { - } \quad \text { What is the input/ output for the specification } \\
\text { - } \quad \text { processes? } \\
\text { - What are the main process steps? } \\
\text { - } \quad \text { How is responsible for each process step? } \\
\text { - } \quad \text { Whocess flow? } \\
\text { - processes and how is it used? } \\
\text { What are the main challenges within the process } \\
\text { flow (e.g., feedback loops, missing information, } \\
\text { need for corrections etc.) }\end{array}$ \\
\hline $\begin{array}{l}\text { Time required } \\
\text { to generate } \\
\text { specifications }\end{array}$ & $\begin{array}{l}\text { LSO (2) } \\
\text { CSU (2) } \\
\text { Development and } \\
\text { engineering (1) } \\
\text { Production (1) }\end{array}$ & $\begin{array}{l}\text { The following questions are asked for the process flows } \\
\text { before and after the implementation of the PCS. } \\
\text { - What are the different specifications generated } \\
\text { by your department (e.g., proposals, BOM, } \\
\text { component workflow (list of operations)? }\end{array}$ \\
\hline
\end{tabular}




\begin{tabular}{|c|c|c|}
\hline & Distribution (1) & $\begin{array}{l}\text { - How many full-time employees are involved in } \\
\text { - } \quad \text { Hour department for making these specifications? } \\
\text { generating the specifications? } \\
\text { - What is your time estimation for the man-hours } \\
\text { and lead-time used for making the specifications } \\
\text { [please give min and max time used and the } \\
\text { distribution] }\end{array}$ \\
\hline $\begin{array}{l}\text { Extent of } \\
\text { reduction in } \\
\text { errors regarding } \\
\text { generated } \\
\text { specifications }\end{array}$ & $\begin{array}{l}\text { CSU (3) } \\
\text { Development and } \\
\text { engineering (1) } \\
\text { Production (1) } \\
\text { Distribution (1) } \\
\text { Product data } \\
\text { management (1) }\end{array}$ & $\begin{array}{l}\text { - In your opinion, do the specifications generated } \\
\text { by the PCS have fewer errors than when you } \\
\text { previously made the same specifications without } \\
\text { the PCS? } \\
\text { - In your opinion what is the reason behind the } \\
\text { improved/decreased numbers of errors when } \\
\text { supported by the PCS? } \\
\text { - What would be the reason for the difference } \\
\text { between the errors in specifications generated } \\
\text { manually and by the PCS (e.g., would product } \\
\text { complexity be an influencing factor?) }\end{array}$ \\
\hline Increase in sales & $\begin{array}{l}\text { LSO (2) } \\
\text { CSU (2) } \\
\text { Product data } \\
\text { management (1) }\end{array}$ & $\begin{array}{l}\text { - Is the level of customer satisfaction affected by } \\
\text { the lead-time? } \\
\text { - How important is lead-time when it comes to a } \\
\text { request for proposal turning into actual sale? }\end{array}$ \\
\hline $\begin{array}{l}\text { Cost of the PCS } \\
\text { (development, } \\
\text { implementation, } \\
\text { and } \\
\text { maintenance) }\end{array}$ & $\begin{array}{l}\text { Product data } \\
\text { management (3) }\end{array}$ & $\begin{array}{l}\text { Development } \\
\text { - } \quad \text { How many people are working on making the } \\
\text { - } \quad \text { How much time of their time did they spend on } \\
\text { the development? } \\
\text { - How many months were spent on the } \\
\text { development of the PCS } \\
\text { Implementation } \\
\text { - How many people were involved in implementing } \\
\text { the PCS? } \\
\text { How much time of their time did they spend on } \\
\text { the implementation? } \\
\text { How many months were spent on the } \\
\text { implementation of the PCS } \\
\text { What is the cost relating to software and } \\
\text { Maintenance } \\
\text { - How many people are involved in the } \\
\text { maintenance of the PCS per year? } \\
\text { How much of their time do they spend on the } \\
\text { maintenance activities per year? }\end{array}$ \\
\hline
\end{tabular}

Additionally, two workshops were held for the main stakeholders from the departments previously mentioned. The first workshop aimed to introduce the purpose of the study and get input on how the data gathering should be scoped and organized. In the second workshop, the findings were presented, discussed, and verified by representatives from those departments. Table 7 summarizes the employees that attended and the agenda for the two workshops. 
Table 7. Workshops guidelines and employees attending the workshops

\begin{tabular}{|c|c|c|}
\hline Departments & No. employees & Agenda \\
\hline $\begin{array}{l}\text { LSO } \\
\text { CSU } \\
\text { Development and } \\
\text { engineering } \\
\text { Production } \\
\text { Distribution } \\
\text { Product data } \\
\text { management } \\
\text { Product } \\
\text { management }\end{array}$ & $\begin{array}{l}\text { The manager and } \\
1-2 \text { employees } \\
\text { from each } \\
\text { department. } \\
\text { In total } 16 \\
\text { employees in } \\
\text { Workshop } 1 \text { and } \\
18 \text { employees in } \\
\text { Workshop } 2\end{array}$ & $\begin{array}{l}\text { Workshop 1: Introduction of the research aim } \\
\text { 1. The scope of the study } \\
\text { - Timeframe } \\
\text { - Product families } \\
\text { 2. Benefits to analyse } \\
\text { 3. Cost structure } \\
\text { 4. Involvement of different employees } \\
\text { 5. Discussions and feedback } \\
\text { Workshop 2: Summary of the main findings from the } \\
\text { research project } \\
\text { 1. Process flow (before and after implementation of the } \\
\text { PCS) } \\
\text { 2. The realized benefits from the PCS } \\
\quad \text { a. Saved man-hours } \\
\quad \text { c. Increased sales } \\
\text { 3. The cost of development, implementation and } \\
\text { maintenance } \\
\text { 4. Further initiatives to improve at the company }\end{array}$ \\
\hline
\end{tabular}

\subsection{Data analysis and validation}

Based on interviews, the process flows before and after the implementation of the PCS are drawn up in order to provide a more fundamental understanding of the process changes when implementing a PCS and to set the presented analysis into context.

The sales numbers are extracted from the company's ERP system for each of the years analyzed for both product families. Only the sales numbers of those products which are supported by the PCS, i.e. CTO and light ETO products, are presented in the analysis. Thus, sales numbers of standard and heavy ETO products are not included since the sales process for these products is not affected by the PCS. Further, the classification of CTO (configured either by LSO or CSU) and light ETO products are available for only one particular year. Hence, the same ratio between the years is used across the entire 5 year period. This can be justified because the ratio is rather constant between years, even though the sales number differs. 
To determine the lead-time and man-hours with respect to time saved in the sales process, project reports and interviews are used. The activities within each of the departments (LSO, CSU, production, distribution, and development and engineering) are first identified, and then the minimum and the maximum times are assigned. This is done to account for the different factors that can influence time consumption, for example, the experience of the salesperson and complexity of the orders. To calculate the costs and the benefits, two assumptions are made, regarding an hourly rate of $50 €$ and a workweek of 37 hours. The hourly rate is based on the internal rate used at the company, and a 37-hour workweek is a standard in Denmark, where the company's headquarters is located. These numbers might not be generalizable outside of Denmark, and to repeat this analysis in companies located in other countries would require adjustments to these assumptions.

The quality of the specifications is measured only for the CSU at the company's headquarters, where analysis was only available for one year. Thus, a comparison before and after the implementation of the PCS was not possible. The analyses include returns of defective products from the production lines, which are divided into seven categories of causes: test data, basis data, error reported, name plate data, bill of materials, other errors, and operations. Each time an error is noticed, it is registered, whether the entry is created manually or by the PCS. Additionally, interviews are used to validate whether the PCS supports improved data quality and increased sales.

Internal validity is achieved by combining data and information from multiple sources that allow for crosschecking i.e. more quantitative data (e.g. based on material taken from internal systems at the companies or project reports) was compared to the information derived from the interviews [57]. Finally, workshops are used to verify that both the scope of the research and the obtained results are acceptable by different 
stakeholders at the company. External validity is achieved by introducing protocols to allow for replication and the results are further validated by comparing the obtained results to the ones reported in the litterature [57].

\section{Results}

\subsection{Background}

The case company introduced in the study, Grundfos, has a world-leading position in pump manufacturing. The company’s headquarters are located in Denmark and employs over 16,000 employees worldwide, with an annual production of more than 16 million pumps. The company offers high-quality solutions that can be fit to different industries. The company first introduced its PCS in 2001, where SAP is used as a platform to build the PCS. The market environment is highly competitive, and thus delivery time and cost are critical. The main motivation for implementing the PCS was to reduce the time required to respond to customer inquiries and thereby increase the company's overall competitiveness.

The main advantage of the PCS and the main goal is that we have reduced the time for creating an offer for a new product, and for creating production specifications from days to minutes. (Lars Hansson, Senior Manager, Product

Data Management and Technical Marketing)

The PCS is used internally at the company by both the LSO and CSU at the company's headquarters. The LSO operate globally and are responsible for all interactions with customers during the sales process. In total, $43 \%$ of the LSO have access to the PCS, which allows them to configure products to a greater extent without having to contact CSU at the company's headquarters. In cases where the LSO do not have access to the PCS, CSU performs the configuration while the LSO interface with the customer. 
Prior to the implementation of the PCS, the company improved the standardization of the product families analyzed in the study, and thus they were good candidates to be supported by the PCS. Both of the product families have predefined configurations, referred to as CTO products that are fully supported by the PCS. In cases where the customer's requirements exceed the coverage of the PCS, the CSU department creates the product specifications manually. Depending on the degree of customization, products are manually created either partially or fully. In the case of partial manual creation, CSU use data from similar configured products in the PCS, and only a few attributes are created manually. The result is referred to as light ETO products. Fully manual creation applies when the customer's requirements are very specialized and cannot be supported by the PCS. These are termed heavy ETO products. Finally, the company also offers standard products, which are classified as a predefined range of configured products that can be selected from.

\subsection{Changes in the product specification process}

This section elaborates on the product specification process before and after PCS implementation.

\subsubsection{The product specification process before PCS implementation}

Before the PCS was implemented, the generation of product specifications involved two different scenarios, which are defined based on standard and ETO products. The first scenario relates to standard products (Figure 1). In this case, a customer orders products that are available on the company's homepage and in different product catalogues through one of the LSO. If the customer is unable to find the product he or she needs, the sales office makes recommendations. For standard products, all product specifications are available. 


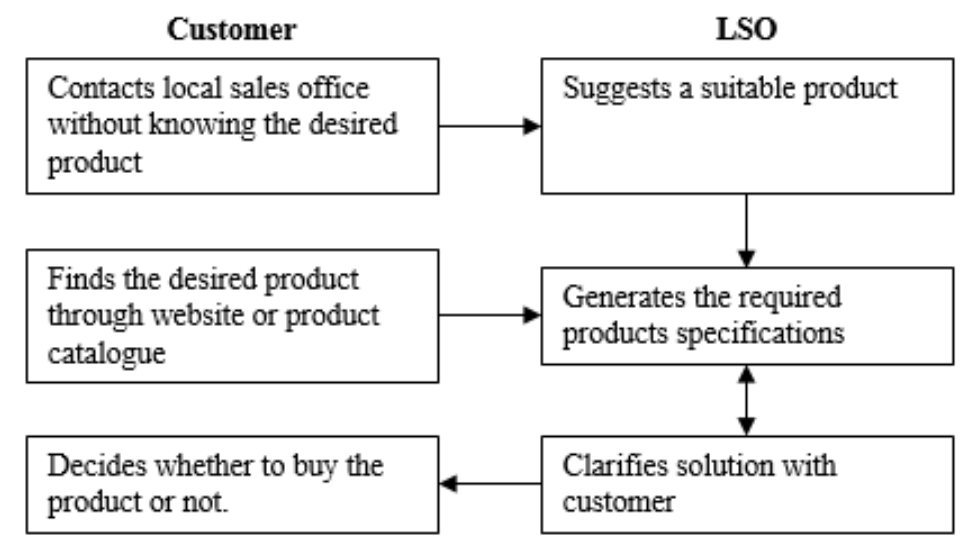

Figure 1. The product specification process for standard products

In the second scenario, customers order non-standard products, including light and heavy ETO products (Figure 2). This requires the involvement of CSU in the sales process, which can result in time-consuming interactions between the customer, LSO, CSU, and the customer. In these cases, the product specifications are generated manually, with the involvement of the engineering and production departments.

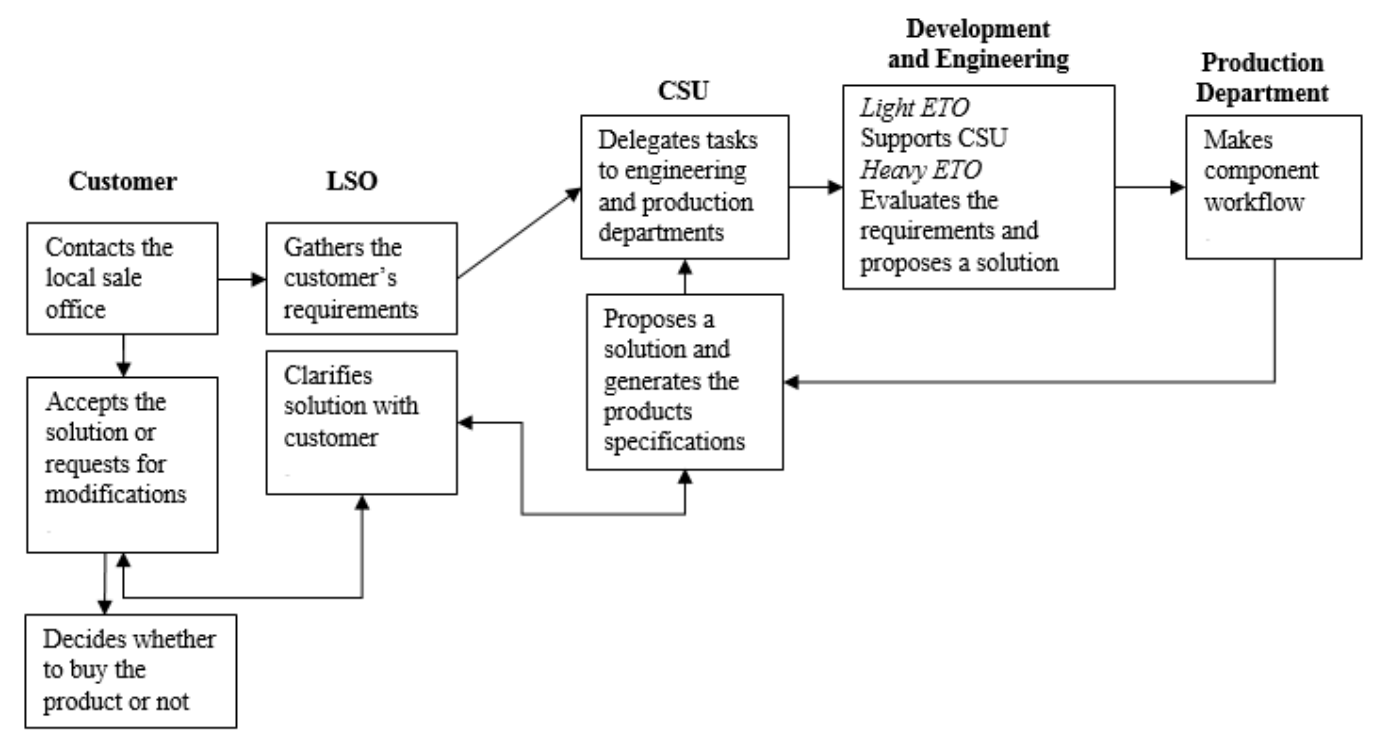

Figure 2. The product specification process for non-standard (light and heavy ETO) products before PCS implementation

The time taken to respond to the customer is one of the main criteria based on which customers decide whether to order a product. A large number of orders processed by the CSU department at the company's headquarters was causing a severe bottleneck 
in the product specification process, due to which customers had to wait up to weeks to receive a response. To address these challenges, the company decided to introduce a PCS to support the product specification process for light ETO products. As the PCS did not affect the product specification process for standardized and heavy ETO products, this study will not further discuss these product types.

\subsubsection{The product specification process after PCS implementation}

The PCS supports the configuration process for light ETO products, which are further divided into light ETO and CTO products. The CTO products were introduced as a part of the standardization project of the product families, which was done prior to the implementation of the PCS. This section presents two scenarios, namely, the configuration process for CTO products and that for light ETO products.

CTO products are configured either by the LSO or CSU. The LSO that have access to the PCS can independently configure the products, generate product specifications, and send them to the customer. However, in cases where the LSO do not have access, the customer's requirements are sent to the CSU, which configures the product via the PCS. The CSU then sends the product specifications back to the LSO, which forwards them to the customer. Figure 3 illustrates the product specification process for CTO products when supported by the PCS.

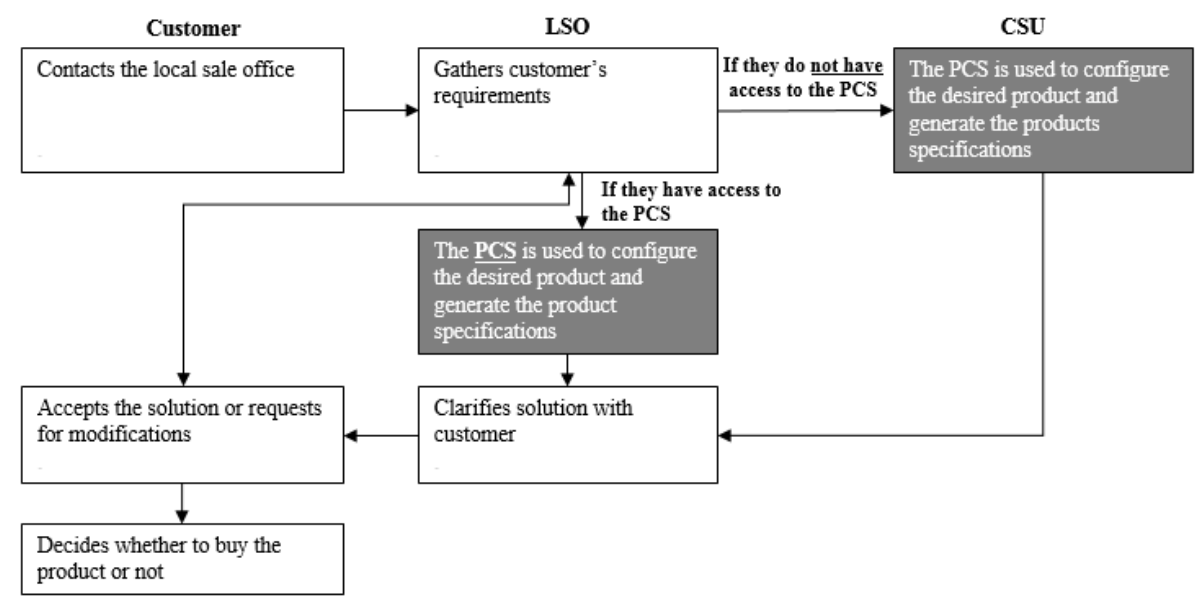

Figure 3. The product specification process for CTO products after PCS implementation 
In the case of light ETO products, the customer requirements exceed the solution space of the PCS. In such cases, the LSO require the assistance of the CSU. The CSU can accordingly delegate the necessary tasks to other departments. The product specifications are created partly manually and partly automatically with the support of the PCS. Figure 4 describes the product specification process for light ETO products supported by the PCS.

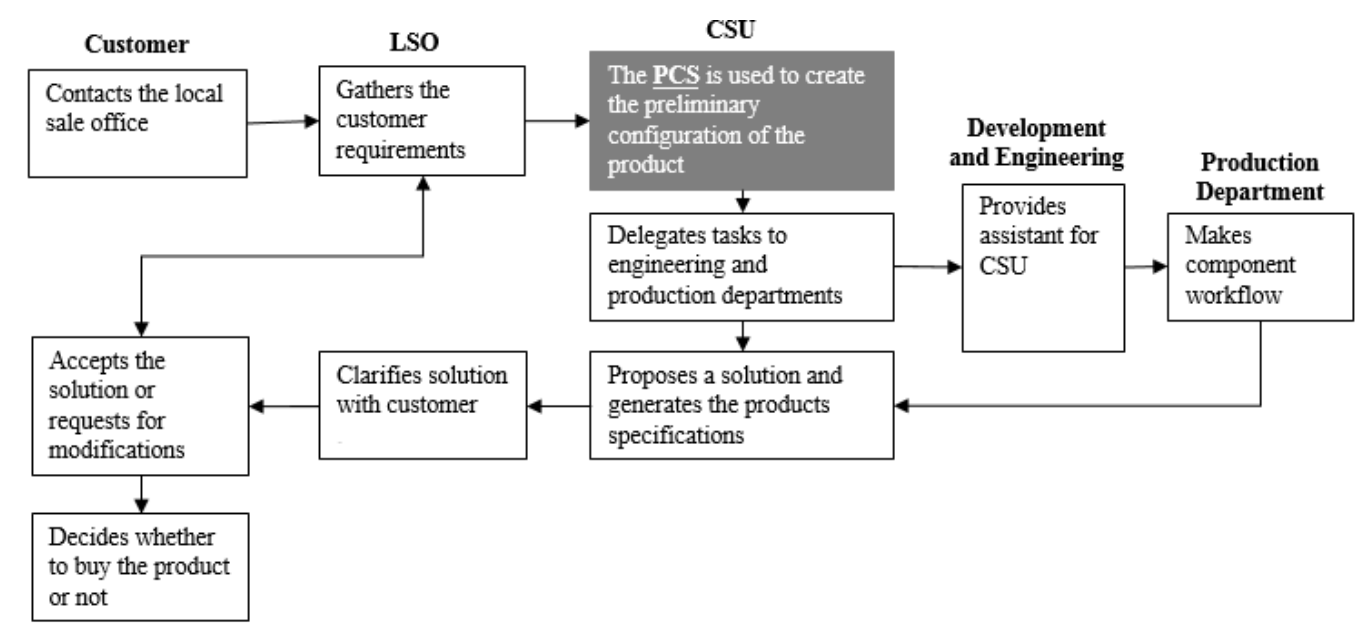

Figure 4. The product specification process for light ETO products after PCS implementation

\subsection{Quantification of the benefits and costs of using the PCS}

This section will quantify the benefits and costs of the PCS to calculate the ROI of the system.

\subsubsection{The main benefits of using the PCS}

This article quantifies the benefits pertaining to resource consumption and lead-time, improved quality of product specifications, and increased sales from using PCS based on a five-year period, as explained in Section 3.

The impact of applying the PCS on resource consumption and lead-time

To estimate the impact of PCS implementation, the quantity of products sold over a five-year period is compared to the amount that would have been sold if the PCS were 
not implemented. To quantify the resource consumption, it is evaluated both when the process was and was not supported by the PCS. The time spent configuring different products can vary due to a number of factors, such as employee experience and product complexity. Therefore, the minimum and maximum times required to generate the product specifications are considered in the calculations presented in this section (Appendix 1). Table 8 presents the time required to create the configuration and generate specifications for different products.

Table 8. The time required to respond to customer orders for CTO and light ETO products

\begin{tabular}{lcccc}
\hline Product types & CTO & CTO & \multicolumn{2}{c}{ Light ETO } \\
Responsible for the configuration & LSO & CSU & CSU \\
\hline Sales offices (hours) & 0.39 & 0.19 & 0.19 \\
CSU (hours) & - & 0.27 & 1.10 \\
Development and engineering (hours) & - & - & 0.54 \\
Production (hours) & - & - & 0.38 \\
Distribution (hours) & - & - & 0.07 \\
\hline Total man-hours (hours) & $\mathbf{0 . 3 9}$ & $\mathbf{0 . 4 6}$ & $\mathbf{2 . 2 8}$ \\
\hline Quotation lead time (days) & $\mathbf{2}$ & $\mathbf{5}$ & $\mathbf{9 . 5}$ \\
\hline
\end{tabular}

The cost savings are calculated by comparing the time consumption of different products before and after the PCS implementation. Since all CTO products were treated as light ETO products prior to implementing the PCS, the time required to generate specifications for these products is used to calculate how much time the product configuration would have taken if not supported by the PCS. To make the calculations more conservative, the analysis assumes that no savings are gained in the case of light ETO products, as they are only partially supported by the PCS. Table 9 shows the total 
average resource consumption (man-hours) when the configuration process was and was not supported by PCS.

Table 9. Man-hours required to respond to customer orders before and after PCS implementation

\begin{tabular}{|c|c|c|c|c|}
\hline \multirow[b]{2}{*}{ Product types } & \multicolumn{3}{|c|}{ With PCS } & \multirow{2}{*}{$\begin{array}{l}\text { Without PCS } \\
\text { Light ETO }\end{array}$} \\
\hline & СТO & СTO & Light ETO & \\
\hline $\begin{array}{l}\text { Responsible for the } \\
\text { configuration }\end{array}$ & LSO & CSU & CSU & CSU \\
\hline $\begin{array}{l}\text { Average time per order } \\
\text { (hours) }\end{array}$ & 0.39 & 0.46 & 2.28 & 2.28 \\
\hline $\begin{array}{l}\text { Total quantity sold over a } \\
\text { five-year period (pieces) }\end{array}$ & 175,699 & 66,553 & 23,960 & 266,212 \\
\hline $\begin{array}{l}\text { Total time spent on orders } \\
\text { over a five-year period } \\
\text { (hours) }\end{array}$ & 68,815 & 30,503 & 54,669 & 607,407 \\
\hline $\begin{array}{l}\text { Weighted average of the } \\
\text { total man-hours spent on } \\
\text { orders over a five-year } \\
\text { period (hours) }\end{array}$ & & 153,988 & & 607,407 \\
\hline
\end{tabular}

As Table 9 shows, the resource consumption for generating quotations reduced significantly; 453,419 man-hours (75\%) were saved due to the implementation of the PCS over a five-year period. Thus, the company saved 22,670,971 $€$ in direct salary costs in the customer order process over the five-year period. PCS implementation also impacted the lead-time for generating quotations, as shown in Table 10.

Table 10. The quotation lead-time (days) before and after PCS implementation

\begin{tabular}{|c|c|c|c|c|}
\hline \multirow[b]{2}{*}{ Product types } & \multicolumn{3}{|c|}{ With PCS } & \multirow{2}{*}{$\begin{array}{l}\text { Without PCS } \\
\text { Light ETO }\end{array}$} \\
\hline & СТO & СТO & Light ETO & \\
\hline $\begin{array}{l}\text { Responsible for the } \\
\text { configuration }\end{array}$ & LSO & CSU & $\mathrm{CSU}$ & CSU \\
\hline Average lead-time (days) & 2 & 5 & 9.5 & 9.5 \\
\hline $\begin{array}{l}\text { Total quantity sold over a } \\
\text { five-year period (pieces) }\end{array}$ & 175,699 & 66,553 & 23,960 & 266,212 \\
\hline
\end{tabular}


As shown in Table 10, the average lead-time for generating quotations reduced from 9.5 days to 3.4 days, which means that 6.1 days (64\%), on average, were saved per quotation generated when the PCS was used.

\section{Improved quality of product specifications}

To measure whether the quality of the product specifications improved after PCS implementation, the number of errors were measured based on the returns of the production lines, which are dived into seven categories: test data, basis data, error reported, name plate data, bill of materials, other errors, and operations. The errors were then divided based on whether they were caused automatically by the PCS or manually by the employees. This analysis covers all the product specifications generated by CSU at the company's headquarters. This department is responsible for generating quotations both fully automatically (CTO), partially automatically (light ETO), and fully manually (heavy ETO). Manual work is required when the requirements exceed the solution space of the system (light ETO = partially manual and heavy ETO = fully manual). Figure 5 presents the results of the analysis for a one-year period.

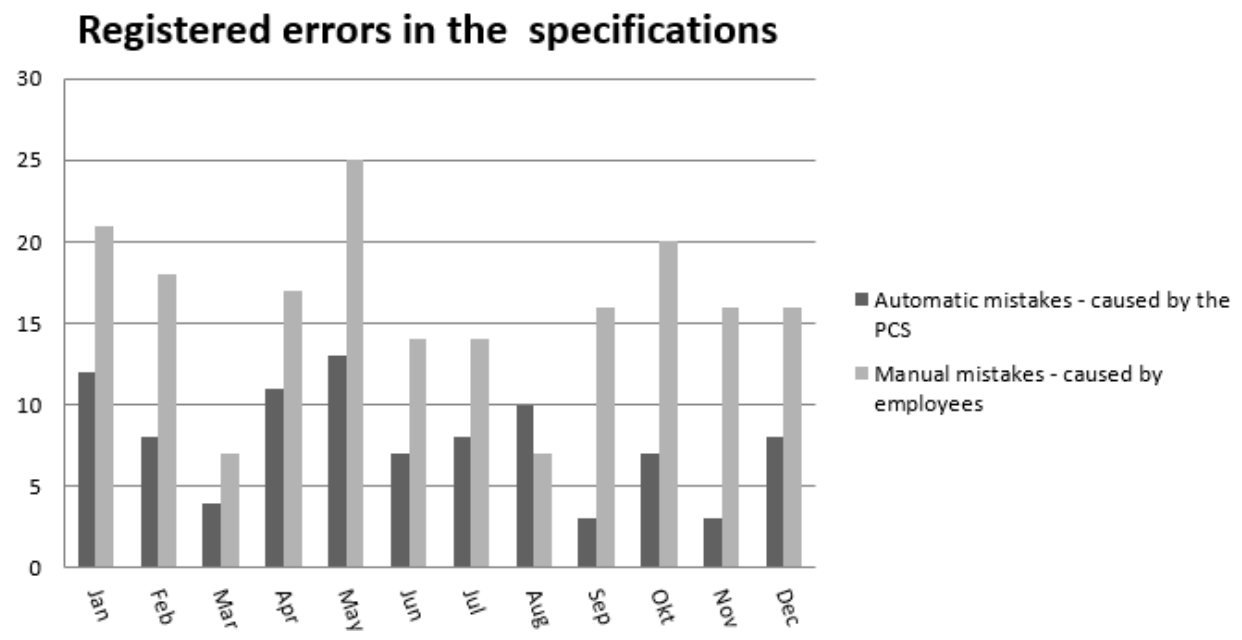


Figure 5. The number of errors reported over a year caused by manual errors and by the PCS

In most cases (except in August), the specifications generated by the PCS have fewer errors per month than those that were generated manually outside the PCS. When the requirements exceed the solution space in the PCS, the specifications must be generated manually. This comparison, therefore, has limitations, as the complexity of the products is higher when the specifications are generated manually. Specialists (employees from sales and production) from the company confirmed, through interviews, that the PCS leads to higher data quality due to a standardized and guided structure. Moreover, the specialists explained that the errors in the specifications generated by the PCS were not caused by the system itself but, in most cases, by the incorrect input.

"It is more efficient to maintain configured products and the configurator ensures global alignment (which improves quality of product data). At the same time, the configurator makes it is more efficient to release product updates for sale globally.” (Lars Hansson, Senior Manager, Product Data Management and Technical Marketing)

Therefore, it can be assumed that if the PCS did not support the generation of specifications, the number of errors would be even higher.

Increased sales due to faster response times

Time and cost are critical factors, based on which customers decide whether to purchase from a given company. Thus, it is assumed that increased responsiveness in the customer order process can lead to increased sales. Increased responsiveness is measured by the productivity of employees and the lead-time in responding to a customer's order. 
The findings show that responding to the same number of orders over a five-year period (266,212 pieces) would require 153,988 man-hours with the PCS and 607,407 man-hours without the PCS. Thus, the PCS helps achieve a productivity increase by a factor of 3.94. Consequently, it can be assumed that 3.94x more resources became available to handle additional customer orders. As previously explained, before the implementation of the PCS, the CSU became a bottleneck in the sales process due to the high number of orders being processed by the department. However, after the PCS was implemented, the number of orders that reached CSU reduced significantly, resulting in

significantly faster response times (from 9.5 days to 3.4 days, or by 64\%). This should, in turn, lower the threat of losing customers to a competitor due to insufficient response time. Even though there is no solid evidence that the use of the PCS led to increased sales, this assumption is supported by the study findings. The PCS reduced lead-time in sales and order handling as well as the workload on the salesmen for making quotations. According to specialists at the company, this has led to increased sales.

\subsubsection{The cost of developing, implementing, and maintaining the PCS}

This section elaborates on the cost associated with the development, implementation, and maintenance of the PCS. A number of different stakeholders are involved in development and implementation; after developing the PCS model, it needs to be tested, training sessions need to be held, and licenses must be acquired in advance. Finally, both the system itself and the product data need to be maintained to ensure that they are up to date and aligned with the company’s offerings.

To render the calculations comparable with those previously described for the benefits, the maintenance cost was calculated over a five-year period. In addition to the maintenance cost, the development cost, which is spread over a two-year period, and the 
cost of implementation, was considered. Table 11 presents the individual costs of the PCS, which are discussed in detail later in this section.

Table 11. The cost associated with developing (two-year period), implementing, and maintaining the PCS (five-year period)

\begin{tabular}{|c|c|c|c|}
\hline Cost elements associated with the PCS & & Amount & Unit \\
\hline \multicolumn{4}{|l|}{ Development } \\
\hline Weekly workload & & 88.8 & Man-hours \\
\hline \multicolumn{2}{|l|}{$\begin{array}{l}\text { Duration of development (over a two-year period prior to PCS } \\
\text { implementation) }\end{array}$} & 2 & Years \\
\hline & Total & 9,235 & Man-hours \\
\hline & Total & 461,760 & $€$ \\
\hline \multicolumn{4}{|c|}{ Implementation (Training and Software) } \\
\hline Estimated total & & 300,000 & $€$ \\
\hline \multicolumn{4}{|l|}{ Maintenance of the PCS } \\
\hline Weekly workload & & 92.5 & Man-hours \\
\hline \multirow[t]{3}{*}{ Duration of maintenance } & & 5 & Years \\
\hline & Total & 24,050 & Man-hours \\
\hline & Total & $1,202,500$ & $€$ \\
\hline \multicolumn{4}{|l|}{ Maintenance of product data } \\
\hline Weekly workload & & 34 & Man-hours \\
\hline \multirow[t]{3}{*}{ Duration of maintenance } & & 5 & Years \\
\hline & Total & 8,840 & Man-hours \\
\hline & Total & 442,000 & $€$ \\
\hline Total cost of development, implementation, and maintenance & & $2,406,260$ & $€$ \\
\hline
\end{tabular}

Cost of development and implementation

There are several roles and responsibilities associated with the development and implementation of the PCS. However, most of the workload was handled by two product configuration engineers, who spent $80 \%$ of their time on development, and a 
product data engineer supervisor, who spent $20 \%$ of his time. Other responsibilities required less than $10 \%$ of the employees' weekly workload, but when considered together, one person was required to spend $60 \%$ of his or her time on the project. Therefore, in total, about 88.8 man-hours per week were spent in developing the PCS model over a two-year period. The development took two years, requiring a total of 9,235 man-hours.

PCS implementation also requires that the necessary training is conducted for the users of the system. One person was responsible for conducting training on both the PCS and the ERP system at the company. The cost of implementation and software, including licenses, maintenance, and upgrades, was estimated to be around 300,000 €.

\section{Cost of maintenance}

Besides the work required for development and implementation, another factor that should be considered is the data maintenance of PCS models, which includes both the PCS model and the product data.

Two full-time persons plus one part-time person who spent $50 \%$ of his or her time were assigned the task of maintaining the PCS models. The weekly workload was therefore estimated to be 92.5 hours; over a five-year period, an estimated 24,050 manhours were spent on software maintenance.

Data maintenance mainly covers product-specific data at three different levels: the sales offices, production sites, and distribution centers. At each level, there is at least one product data engineer working in close collaboration with the configuration engineers, as product-specific data is constantly updated. The amount of work required to maintain the data at the sales offices and distribution centers was relatively low, estimated at $0.5 \%$ of the total workload for each location. In this case, the production facilities had to allocate additional resources for data maintenance. An estimated 34 
man-hours per week were required to maintain product-specific data. In total, around 8,840 man-hours were required over the five-year period.

\subsubsection{The realized return on investment for the PCS}

By comparing the direct cost savings due to reduced man-hours to the direct cost of developing, implementing and maintaining the PCS, it can be concluded that the PCS is highly beneficial for the company within the five-year period analysed. The realised ROI for the PCS can be calculated based on the findings presented of the benefits and the costs of the PCS. In Table 12, the main findings of the case study are summarised, and the ROI is calculated for both one year and five years after implementation.

Table 12. ROI from applying PCS over a five-year period

\begin{tabular}{lcc}
\hline Cost saving and cost factors associated with the PCS & Amount & Unit \\
\hline Reduced man-hours in the ordering process & 75 & $\%$ \\
Cost savings based on saved hours over a five-year period & $22,670,971$ & $€$ \\
Cost of development, implementation and maintenance over a five-year period & $2,406,260$ & $€$ \\
Total cost savings over a five-year period & $\mathbf{2 0 . 2 6 4 . 7 1 1}$ & $€$ \\
\hline Realised ROI & & \\
\hline ROI (one year after implementation) & 316 & $\%$ \\
ROI (five years after implementation) & 842 & $\%$ \\
\hline Other benefits that could not be quantified & & \\
\hline Lead time savings (average) & 3.4 & Days \\
Lead time savings (average) & 64 & $\%$ \\
Increase in sales output through PCS & 3.94 & x \\
\hline
\end{tabular}

\section{Discussions and conclusion}

This study aims to first propose a method to calculate the value creation from utilizing a PCS by providing answer to the research question How to quantify the costs, benefits and ROI from developing, implementing and utilizing PCS? and second to provide 
empirical evidence based on a case study to answer to the research question What are the costs, benefits, and ROI from developing, implementing and utilizing a PCS?

Comparing benefits based on the reduced man-hours to the cost of developing, implementing, and maintaining the PCS, the PCS was found to be highly beneficial for the case company across the five-year period analyzed. Furthermore, this study provides insight on how a PCS can be used in companies producing both standardized and highly engineered products.

The analyses revealed that the case company saved 453,419 man-hours over a five-year period by utilizing the PCS, which corresponds to a 75\% reduction of manhours used in the sales process. This is aligned with other research, which has also reported significant time reductions in manned activities [e.g., 24,40,44,47]. Further, the lead-time for responding to customers was also reduced from 9.5 to 3.4 days, on average, or by $64 \%$. Other researchers have also quantified this improvement, reporting a significant reduction in lead-time [e.g., 39,40,47]. Additionally, improved quality of the product specifications when supported by the PCS, as well as increased sales, were identified as benefits of utilizing the PCS.

The direct cost was divided into three groups: the costs of development, implementation, and maintenance. The development of the PCS was performed over two years and cost $461,760 €$, with total implementation costs of $300,000 €$. The maintenance was divided into the maintenance of the PCS and of the product data. Over a five-year period, the cost of maintenance was estimated to be $1,202,500 €$ for the PCS and 442,000 $€$ for the product data. Thus, in total, the cost of the PCS for the two product families considered in the study was 2,406,260 €. PCS-related cost is discussed by a few researchers [6,47]. Hvam [47] calculates the cost of development and implementation of a PCS to be $\$ 1$ million and operating costs to be about $\$ 100,000$. 
However, in that study, the development cost is higher while the maintenance cost is lower compared to the analysis presented in this study. Several factors could explain this difference, including ongoing development in the maintenance phase, the complexity of the data that need to be managed, and changes in the product design. As in Hvam [47], the cost elements are not broken down, and this makes it difficult to find the underlying difference.

Based on the findings presented in this study it can be concluded that the PCS is highly beneficial for the company: Over a five-year period, the company saved $20,264,711 €$, with an $842 \%$ ROI for the PCS. Further, if the previously described benefits of PCS use were interdependent, even greater value creation would be possible. There are several examples of how these benefits can interact: First, fewer errors in product specifications would lead to additional savings in resource consumption and reduced lead-time, as errors would not have to be corrected. Second, using a PCS can enable employees to engage in a better dialogue with customers, which would also reduce resource consumption and lead-time. In this case, fewer resources would be required to work on the product specification, creating additional time that could be used to undertake specialized orders and improve the product platform. Third, reduced lead-time could also result in increased sales because this reduces the risk of the customer going elsewhere since time is a competitive factor. In this manner, higher value creation can be identified from the use of a PCS; in other words, actual value created by the PCS might be even higher.

Companies with a product portfolio consisting of a standard to engineered products could therefore potentially enjoy significant benefits and positive ROI by using a PCS, in addition to improving the standardization of their product range by supporting the product specification processes for CTO and light versions of ETO products. This 
study illustrates how a PCS can be used to partially support a company's product portfolio. This is consistent with the literature, which indicates that it might not be economically feasible to have the PCS supporting the most complex products, especially if the sales volume is low [6,32]. Based on the different archetypes of ETO companies as defined by Willner et al. [34] the company studied can be defined as repeatable ETO that should be characterized by high standardization and design automation.

This research constitutes the first step towards analyzing and quantifying the ROI of using a PCS. The authors recognize the limitation of the study, as it is based on a case study of one company, which may lead to findings that are too narrow in their application [58]. Thus, it is not argued that the ROI of the PCS in this study is generalizable. But, on a more conceptual level, this study shows that PCSs can be highly beneficial, which is aligned with the literature. The approach to the PCS setup and the configuration platform (SAP) should be applicable to other manufacturing companies making both standard and engineered solutions. Further, the article detailed how the benefits, costs, and ROI from implementing and utilizing a PCS can be calculated, which can be used in other companies. Thus, the findings presented in the study should support increased maturity of the PCS research area by shedding light on a less explored area of the PCS or the cost side and lay a foundation for further studies to analyze this based on other companies.

In order to find a benchmark for the ROI, further studies are needed, in addition to criteria related to the circumstances under which the benchmarking is valid. This could e.g., include analysis of differing ETO companies [35,36,59] to see if the benefits realization from PCS would differ across those types. Another aspect that might be interesting to further study is the relation between the benefits realization companies 
achieve and the maturity of the companies working with design automation. Based on Willner et al. [52], the maturity of an organization is increasing based on the level of standardization of products and processes. This could be directly linked to the expected realized benefits associated with the utilization of a PCS. It is expected that the more mature the organization is; the more benefits it can gain from the PCS utilization. Even though Willner's research focuses on ETO companies, the underlying principles can also be used for manufacturers $\theta f$ having more diverse product portfolios i.e. varying from standard to ETO products. Further studies should therefore focus on combining the benefit realization to the maturity level of the manufacturing company, regarding both standard and ETO products. This would be beneficial not only to the research community, but also to practitioners, as based on the maturity model, it would reveal the expected benefits.

\section{References}

[1] L. Hvam, N.H. Mortensen, J. Riis, Product customization, Springer, Berlin Heidelberg, 2008.

[2] B.J. Pine II, B. Victor, Boyton, Making mass customization work, Harv. Bus. Rev. 71 (1993) 109-119.

[3] F. Salvador, P.M. De Holan, F.T. Piller, Cracking the Code of Mass Customization, MIT Sloan Manag. Rev. 50 (2009) 71-78.

[4] A. Felfernig, G.E. Friedrich, D. Jannach, UML as Domain Specific Language for the Construction of Knowledge-based Configuration Systems, Int. J. Softw. Eng. Knowl. Eng. 10 (2000) 449-469.

[5] K. Kristjansdottir, S. Shafiee, L. Hvam, How to identify possible applications of product configuration systems in Engineer-to-Order companies, Int. J. Ind. Eng. Manag. 8 (2017).

[6] C. Forza, F. Salvador, Managing for variety in the order acquisition and fulfilment process: The contribution of product configuration systems, Int. J. Prod. Econ. 76 (2002) 87-98. doi:10.1016/S0925-5273(01)00157-8.

[7] L.L. Zhang, E. Vareilles, M. Aldanondo, Generic bill of functions, materials, and operations for SAP2 configuration, Int. J. Prod. Res. 51 (2013) 465-478. doi:10.1080/00207543.2011.652745.

[8] A. Trentin, E. Perin, C. Forza, Product configurator impact on product quality, Int. J. Prod. Econ. 135 (2012) 850-859. doi:10.1016/j.ijpe.2011.10.023.

[9] F. Salvador, C. Forza, Configuring products to address the customizationresponsiveness squeeze: A survey of management issues and opportunities, Int. J. Prod. Econ. 91 (2004) 273-291. doi:10.1016/j.ijpe.2003.09.003.

[10] A. Myrodia, K. Kristjansdottir, L. Hvam, Impact of product configuration 
systems on product profitability and costing accuracy, Comput. Ind. 88 (2017) $12-18$.

[11] A. Trentin, E. Perin, C. Forza, Sales configurator capabilities to avoid the product variety paradox: Construct development and validation, Comput. Ind. 64 (2013) 436-447. doi:10.1016/j.compind.2013.02.006.

[12] A. Trentin, E. Perin, C. Forza, Increasing the consumer-perceived benefits of a mass-customization experience through sales-configurator capabilities, Comput. Ind. 65 (2014) 693-705. doi:10.1016/j.compind.2014.02.004.

[13] E. Sandrin, A. Trentin, C. Grosso, C. Forza, Enhancing the consumer-perceived benefits of a mass-customized product through its online sales configurator, Ind. Manag. Data Syst. 117 (2017) 1295-1315. doi:10.1108/IMDS-05-2016-0185.

[14] E. Sandrin, Synergic effects of sales-configurator capabilities on consumerperceived benefits of mass-customized products, Int. J. Ind. Eng. Manag. 8 (2017) 177-188.

[15] F. Piller, K. Moeslein, C. Stotko, Does mass customization pay? An economic approach to evaluate customer integration, Prod. Plan. Control. (2004).

[16] A. Felfernig, D. Jannach, M. Zanker, Contextual diagrams as structuring mechanisms for designing configuration knowledge bases in UML, UML» 2000 -The Unified Model. Lang. (2000) 240-254.

[17] L. Ardissono, A. Felfernig, G. Friedrich, A. Goy, D. Jannach, G. Petrone, R. Schäfer, M. Zanker, A framework for the development of personalized, distributed web-based configuration systems, AI Mag. 24 (2003) 93-108.

[18] L.L. Zhang, Product configuration: a review of the state-of-the-art and future research, Int. J. Prod. Res. 52 (2014) 6381-6398. doi:10.1080/00207543.2014.942012.

[19] C. Forza, F. Salvador, Product information management for mass customization, Palgrave Macmillan, New York, 2007.

[20] K. Kristjansdottir, S. Shafiee, L. Hvam, M. Boven, A. Myrodia, Quantification of Benefits and Cost from Applying a Product Configuration System, Proc. 7th Int. Conf. Mass Cust. Pers. Cent. Eur. (MCP-CE 2016). (2016).

[21] V.E. Barker, D.E. O’Connor, J. Bachant, E. Soloway, Expert systems for configuration at Digital: XCON and beyond, Commun. ACM. 32 (1989) 298318. doi:10.1145/62065.62067.

[22] G. Fleischanderl, G.E. Friedrich, A. Haselböck, H. Schreiner, M. Stumptner, Configuring large systems using generative constraint satisfaction, IEEE Intell. Syst. 4 (1998) 59-68. http://www.computer.org/csdl/mags/ex/1998/04/x4059.pdf (accessed March 22, 2015).

[23] J.J. Sviokla, An Examination of the Impact of Expert Systems on the Firm: The Case of XCON, MISQ. 14 (1990) 127-140. doi:10.2307/248770.

[24] C. Forza, F. Salvador, Product configuration and inter-firm co-ordination: an innovative solution from a small manufacturing enterprise, Comput. Ind. 49 (2002) 37-46. doi:10.1016/S0166-3615(02)00057-X.

[25] P.P. Phillips, J.J. Phillips, Return on Investment, in: Handb. Improv. Perform. Work. Vol. Two Sel. Implement. Perform. Interv., 2010: pp. 823-846. http://onlinelibrary.wiley.com/doi/10.1002/9780470587102.ch34/summary (accessed February 5, 2017).

[26] S. Mittal, F. Frayman, Towards a Generic Model of Configuraton Tasks, IJCAI. 89 (1989) 1395-1401. http://www.ijcai.org/Proceedings/89-2/Papers/087.pdf (accessed August 29, 2017).

[27] C. Forza, F. Salvador, Product information management for mass customization: 
connecting customer, front-office and back-office for fast and efficient customization, Palgrave Macmillan, New York, 2006.

doi:10.1057/9780230800922.

[28] S. Shafiee, K. Kristjansdottir, L. Hvam, Automatic identification of similarities across products to improve the configuration process in ETO companies, Int. J. Ind. Eng. Manag. 8 (2017).

[29] K. Ulrich, The role of product architecture in the manufacturing firm, Res. Policy. 24 (1995) 419-440. doi:10.1016/0048-7333(94)00775-3.

[30] S.D. Eppinger, K.T. Ulrich, Product design and development, (2000).

[31] M. Rudberg, J. Wikner, Mass customization in terms of the customer order decoupling point, Prod. Plan. Control. 15 (2004) 445-458.

doi:10.1080/0953728042000238764.

[32] A. Haug, K. Ladeby, K. Edwards, From engineer-to-order to mass customization, Manag. Res. News. 32 (2009) 633-644. doi:10.1108/01409170910965233.

[33] S.H. Markworth Johnsen, K. Kristjansdottir, L. Hvam, Improving product configurability in ETO companies, in: Proc. Int. Conf. Eng. Des. ICED, 2017.

[34] O. Willner, D. Powell, M. Gerschberger, P. Schönsleben, Exploring the archetypes of engineer-to-order: an empirical analysis, Int. J. Oper. Prod. Manag. 36 (2016) 242-264. doi:10.1108/IJOPM-07-2014-0339.

[35] W. J.a, R. M.b, Integrating production and engineering perspectives on the customer order decoupling point, Int. J. Oper. Prod. Manag. 25 (2005) 623-641. doi:10.1108/01443570510605072.

[36] J. Gosling, B. Hewlett, M.M. Naim, Extending customer order penetration concepts to engineering designs, Int. J. Oper. Prod. Manag. 37 (2017) 402-422. doi:10.1108/IJOPM-07-2015-0453.

[37] M. Ariano, A. Dagnino, An intelligent order entry and dynamic bill of materials system for manufacturing customized furniture, Comput. Electr. Eng. 22 (1996) 45-60. doi:10.1016/0045-7906(95)00027-5.

[38] M. Aldanondo, S. Rougé, M. Véron, Expert configurator for concurrent engineering: Cameleon software and model, J. Intell. Manuf. 11 (2000) 127-134. doi:10.1023/a:1008982531278.

[39] M. Gronalt, M. Posset, T. Benna, Standardized Configuration in the Domain of Hinterland Container Terminals, Ser. Bus. Informatics Appl. Syst. Innov. Process. Prod. Mass Cust. 3 (2007) 105-120.

[40] C. Forza, A. Trentin, F. Salvador, Supporting product configuration and form postponement by grouping components into kits: the case of MarelliMotori, Int. J. Mass Cust. 1 (2006) 427-444.

[41] A. Haug, L. Hvam, N.H. Mortensen, The impact of product configurators on lead times in engineering-oriented companies, Artif. Intell. Eng. Des. Anal. Manuf. 25 (2011) 197-206. doi:10.1017/S0890060410000636.

[42] M. Heiskala, K. Paloheimo, J. Tiihonen, Mass customization of services: benefits and challenges of configurable services, Front. E-Bus. Res. (FeBR 2005). (2005) 206-221.

[43] M. Heiskala, J. Tihonen, K. Paloheimo, T. Soininen, Mass customization with configurable products and configurators: a review of benefits and challenges, in:

[44] J. Heatley, R. Agarwal, M. Tanniru, An evaluation of an innovative information technology—-the case of Carrier EXPERT, J. Strateg. Inf. Syst. 4 (1995) 255277.

[45] L. Hvam, M. Malis, B. Hansen, J. Riis, Reengineering of the quotation process: application of knowledge based systems, Bus. Process Manag. J. 10 (2004) 200- 
213. doi:10.1108/14637150410530262.

[46] L. Hvam, Mass Customization in the electronics industry: based on modular products and product configuration, Int. J. Mass Cust. 1 (2006) 410-426.

[47] L. Hvam, Mass customisation of process plants, Int. J. Mass Cust. 1 (2006) 445462.

[48] L. Hvam, A. Haug, N.H. Mortensen, C. Thuesen, Observed benefits from product configuration systems, Int. J. Ind. Eng. Theory, Appl. Pract. 20 (2013).

[49] T.D. Petersen, Product Configuration in ETO Companies, in: T. Blecker (Ed.),

[50] J. Tiihonen, T. Soininen, T. Männistö, R. Sulonen, State of the practice in product configuration-a survey of 10 cases in the finnish industry, Knowl. Intensive CAD. (1996) 95-114.

[51] B. Yu, H. Skovgaard, A configuration tool to increase product competitiveness, IEEE Intell. Syst. 4 (1998) 34-41.

[52] C. Voss, Case research in operations management, in: C. Karlsson (Ed.), Res. Oper. Manag., Routledge, Taylor \& Francis Group, 2009: pp. 162-195.

[53] J. Meredith, Building operations management theory through case and field research, J. Oper. Manag. 16 (1998) 441-454. doi:10.1016/S02726963(98)00023-0.

[54] R.K. Yin, Case Study Research, Fifth Edit, New York, 2013.

[55] K.M. Eisenhardt, Better stories and better constructs: The case for rigor and comperative logic. Acad. Manag. Rev. 16 (1991) 620-627. doi:10.5465/AMR.1991.4279496.

[56] T.D. Jick, Mixing Qualitative and Quantitative Methods: Triangulation in Action, Adm. Sci. Q. 24 (1979) 602. doi:10.2307/2392366.

[57] R.K. Yin, Case Study Research Design and Methods, Fifth edit, Thousand Oaks, CA: Sage, 2014. doi:https://doi.org/10.3138/cjpe.30.1.108, 10.3138/cjpe.

[58] K.M. Eisenhardt, Building Theories from Case Study Research, Acad. Manag. Rev. 14 (1989) 532-550. doi:10.5465/AMR.1989.4308385.

[59] O. Willner, J. Gosling, P. Schönsleben, Establishing a maturity model for design automation in sales-delivery processes of ETO products, Comput. Ind. 82 (2016) 57-68. doi:10.1016/j.compind.2016.05.003. 


\section{Appendix 1}

Resource consumption (man-hours) used to respond to customers' orders

\begin{tabular}{|c|c|c|c|c|c|c|}
\hline \multirow[b]{2}{*}{ Responsible for the configuration } & \multicolumn{2}{|l|}{ CTO } & \multicolumn{2}{|l|}{ СTO } & \multicolumn{2}{|c|}{ Light ETO } \\
\hline & LSO & & CSU & & CSU & \\
\hline & Min & $\operatorname{Max}$ & Min & $\operatorname{Max}$ & Min & $\operatorname{Max}$ \\
\hline Distribution & $50 \%$ & $50 \%$ & $50 \%$ & $50 \%$ & - & - \\
\hline Sales offices (hours) & 0.20 & 0.58 & 0.13 & 0.25 & $0.13^{*}$ & $0.25 *$ \\
\hline CSU (hours) & - & - & 0.20 & 0.33 & $1.00 * *$ & $1.50 * *$ \\
\hline Development and Engineering (hours) & - & - & - & - & $0.08 *$ & $1.00 *$ \\
\hline Production (hours) & - & - & - & - & $0.03 * * *$ & $7.00 * * *$ \\
\hline Distribution (hours) & - & - & - & - & $0.05^{*}$ & $0.08 *$ \\
\hline $\begin{array}{l}\text { Total man-hours weighted average } \\
\text { (hours) }\end{array}$ & & & & & & \\
\hline
\end{tabular}

* $\quad$ Distribution min 50\% max 50\%

** $\quad$ Distribution min $80 \% \max 20 \%$

*** Distribution min 95\% max 5\%

Lead-time of generating quotation

\begin{tabular}{|c|c|c|c|c|c|c|}
\hline \multirow[b]{2}{*}{ Responsible for the configuration } & \multicolumn{2}{|l|}{ CTO } & \multicolumn{2}{|l|}{ СTO } & \multicolumn{2}{|c|}{ Light ETO } \\
\hline & LSO & & $\mathrm{CSU}$ & & $\mathrm{CSU}$ & \\
\hline & Min & $\operatorname{Max}$ & Min & Max & Min & $\operatorname{Max}$ \\
\hline Distribution & $50 \%$ & $50 \%$ & $50 \%$ & $50 \%$ & $50 \%$ & $50 \%$ \\
\hline Quotation lead time (days) & 1 & 3 & 3 & 7 & 7 & 12 \\
\hline $\begin{array}{l}\text { Quotation lead time weighted } \\
\text { average (days) }\end{array}$ & & & & & & \\
\hline
\end{tabular}

